\title{
Multibeam bathymetry and the depositional environments of Kongsfjorden and Krossfjorden, western Spitsbergen, Svalbard
}

\author{
John A. Howe, Steven G. Moreton, \\ Clara Morri \& Peter Morris
}

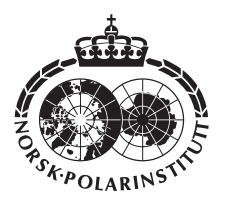

Kongsfjorden and Krossfjorden are two ice-proximal fjords on the western coast of Spitsbergen which have been surveyed using multibeam bathymetry, sub-bottom profiling and gravity coring. Central and outer Kongsfjorden is dominated by a $30 \mathrm{~km}^{2}$ outcrop of bedrock, with a thin $(<10 \mathrm{~m})$ sediment cover. The bedrock displays a relict sub-glacial, ice-scoured topography produced during the glacial re-advances of the Weichselian (20 Ky BP) and again during the last major Holocene re-advance of the Little Ice Age (550 - $200 \mathrm{yrs}$ BP). Drumlins and glacial flutes are common across the floor of Kongsfjorden, with lengths of 1.5-2.5 km and widths of $<100 \mathrm{~m}$, rising up to $10 \mathrm{~m}$ in water depths of $<100 \mathrm{~m}$. This topography is smoothed by bottom currents from the wind-driven forcing of surface waters. The flow is counter-clockwise, matching boundary layer movement under the influence of Coriolis force. Both fjords are characterized by a variable acoustic character, based on sub-bottom profile data. The deepest basins are dominated by parallel, well-laminated reflectors and an irregular-transparent acoustic character indicating the presence of Holocene-age fine-grained sediments up to $30 \mathrm{~m}$ thick. A parallel, irregular-transparent acoustic character with waveform morphology in inner Kongsfjorden is interpreted as moraines, originating from the 1948 and 1869 surges of Kronebreen glacier. Mass-flows are common on the flanks of topographic highs as acoustically chaotic-transparent lensoid and wedge-shaped reflectors. The sediments of outer and central Kongsfjorden are characterized by bioturbated, gas-rich homogeneous muds interpreted as being the result of the settling of fine-grained sediment and particulate suspensions.

J. A. Howe \& C. Morri, Scottish Association for Marine Science, Dunstaffnage Marine Laboratory, Dunbeg, Oban, Argyll PA37 1IQ, Scotland, UK, jaho@dml.ac.uk; S. G. Moreton, NERC Radiocarbon Laboratory, Scottish Enterprise Technology Park, Rankine Avenue, East Kilbride, Glasgow G75 0QF, UK; P. Morris, British Antarctic Survey, High Cross, Madingley Road, Cambridge CB3 OET, UK.

High latitude glaciomarine depositional environments are geologically significant in that they contain sediment records trapped by their basinsill morphology that have the potential to preserve a detailed record of climatic variability in polar regions. Glacier-influenced fjords have been studied using acoustic surveys from polar and sub-polar regions in both the Arctic and Antarctic (Elverhøi et al. 1980; Powell \& Molnia 1989; Syvitski \& Praeg 1989; Bartek et al. 1997; DaSilva et al. 1997). The use of multibeam bathymetric surveys to map the seafloor morphology of 


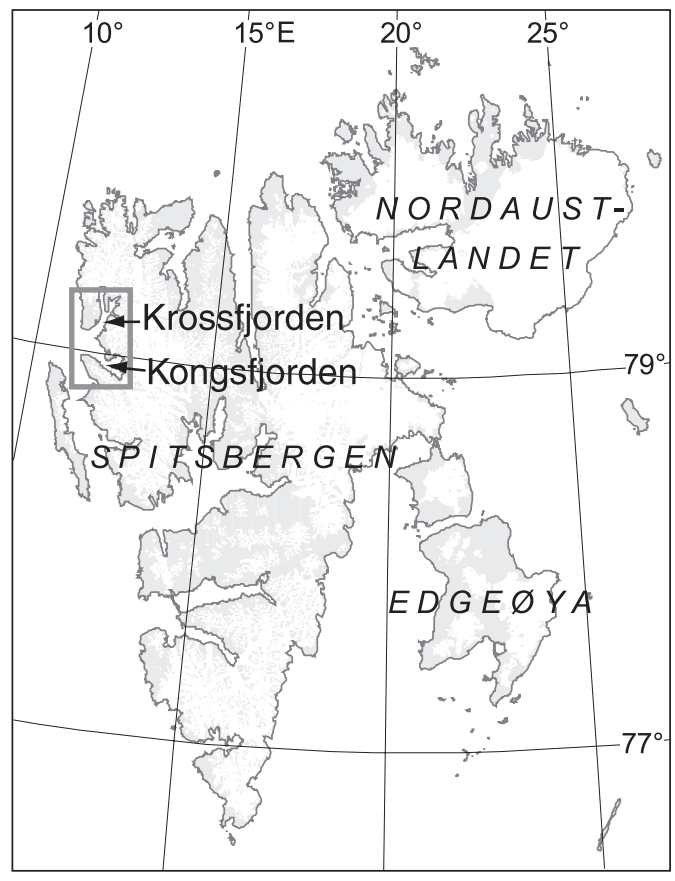

Fig. 1. Map of the main islands of Svalbard indicating the location of RRS James Clark Ross multibeam and Topas subbottom profiling and gravity core survey in Kongsfjorden and Krossfjorden, western Spitsbergen.

polar regions has been used extensively to identify glacial modification of the seafloor and other large-scale morphological features related to ice movement (Shaw \& Courtney 1997; Shipp \& Anderson 1997).

Since 1980, acoustic seafloor data have been collected from Kongsfjorden and Krossfjorden, western Spitsbergen, Svalbard, by a number of workers to document the glaciomarine sedimentary environments and their depositional chronology. In Kongsfjorden, the most notable work in this field was the early surveys conducted by Elverhøi et al. $(1980,1983)$ and later by Sexton et al. (1992), which provide the basic seismic stratigraphy referred to in this paper. Although a similar profile has been illustrated before (Sexton et al. 1992), we present new multibeam bathymetry and corresponding sub-bottom profile (Topas) data that illustrate both the seismic stratigraphy and seabed morphology of the fjord. The seabed survey was obtained during the July 2002 Arctic cruise of the RRS James Clark Ross, as part of the Scottish Association of Marine Science Northern Seas project. One of the main aims of this project is to examine signals of recent climatic amelioration from mid- to high latitude marine sediments using the proxies of sediment texture, type and geochemistry. Utilizing the high sedimentation rates of the Polar North Atlantic (3-100 cm/Ky [thousand years]; Elverhøi et al. 1998), climatic events can be detected at a high temporal resolution allowing the timing and onset of climatic events and their relationship to sediment supply and biogenic productivity to be examined.

Here we present a detailed multibeam bathymetric map and corresponding sub-bottom profiles of the Kongsfjorden area to document the modern and short-term historical glaciomarine depositional environments of the fjord system. A $6 \mathrm{~m}$ long gravity corer was also used to obtain sediment records from the fine-grained basinal fjord sites in Kongsfjorden.

\section{Regional setting}

\section{Physiography}

Kongsfjorden and Krossfjorden are two fjord systems, sharing a combined mouth, located between $78^{\circ} 40^{\prime}$ and $77^{\circ} 30^{\prime} \mathrm{N}$ and $11^{\circ} 3^{\prime}$ and $13^{\circ} 6^{\prime} \mathrm{E}$ on the western coast of Svalbard (Fig. 1). The fjords consist of two basins combining at their seaward limits to form the main submarine glacial trough, the Kongsfjordrenna. Kongsfjorden, the more southerly of the two fjords, is oriented south-east to north-west. Krossfjorden lies to the north of Kongsfjorden and is oriented north to south. Total drainage for both fjords is $3074 \mathrm{~km}^{2}$ (Svendsen et al. 2002). Kongsfjorden is $20 \mathrm{~km}$ long, varying in width from $4-10 \mathrm{~km}$. The fjord can be divided into an inner fjord with water depths of less than $100 \mathrm{~m}$ and a deeper central and outer fjord basin. The deepest point of Kongsfjorden is $-394 \mathrm{~m}$ in the outer fjord basin. The total area of Kongsfjorden is estimated as $29.4 \mathrm{~km}^{3}$ (Ito \& Kudoh 1997). A number of tidewater glaciers drain into Kongsfjorden: Kronebreen, Kongsbreen and Kongsvegen at its head, and Conwaybreen and Blomstrandbreen on its northern coast (see Fig. 2 in Svendsen et al. 2002). Krossfjorden is $30 \mathrm{~km}$ long and varies in width from $3-6 \mathrm{~km}$. Its volume is estimated as $25 \mathrm{~km}^{2}$. The deepest point of Krossfjorden is $-375 \mathrm{~m}$ in the inner fjord. It also has a number of glaciers draining into it, notably Lilliehöökbreen at its head.

Multibeam bathymetry and depositional environments 


\section{Geology}

The region encompassing Kongsfjorden and Krossfjorden is situated on the tectonic boundary between a Teriary fold-thrust belt that extends across western Spitsbergen and the Northwestern Basement Province, which lies to the north-east (Bergh et al. 2000). Kongsfjorden has formed in a depression formed from bedrock fracturing parallel to the thrust front. North of Kongsfjorden, the bedrock consists of medium-grade metamorphic marbles, mica-schists and quartzites of middle Proterozoic age. The islands of Blomstrandhalvøya and Lovénøyane (Fig. 2) comprise Devonian red conglomerates and sandstones, interlayered with marbles. South of Kongsfjorden, Brøggerhalvøya (Brøgger peninsula; Fig. 2) displays the Tertiary thrust with Palaeozoic sediments comprising conglomerates, sandstones, carbonates and dolomites occurring on the south-east of the peninsula. In the vicinity of Ny-Ålesund, two Tertiary thrust sheets comprise conglomerates, sandstones and shales interbedded with coal (Svendsen et al. 2002). The entire area surrounding Krossfjorden and Kongsfjorden has been subject to glacial activity. Brøggerhalvøya experienced four isostatically-induced cycles of late Weischselian glaciation (Miller et al. 1989). All the glaciers had begun to retreat during the early Holocene (9500 yrs BP) and the region was ice-free until 4500 yrs $\mathrm{BP}$, when maximum Holocene ice extent was reached during the Little Ice Age (H. Svendsen et al. 2002). At the present time, as elsewhere on Svalbard, all the glaciers are currently retreating.

\section{Sedimentation and depositional processes}

Sedimentation in both Kongsfjorden and Krossfjorden is strongly influenced by the glaciers and the seasonal generation of sea ice. A number of studies have been conducted on the sedimentation in Kongsfjorden, notably on the suspended particulate matter (see Svendsen et al. 2002 for a detailed review of this subject). The suspended particulate matter has a key influence on a number of physical parameters within the fjord, such as: the extent of the euphotic zone and the consequence for primary production; heat exchange with the atmosphere; flocculation of particles and colloids; direct impact on the benthos and the physical-chemical and geotechnical properties of the sea floor (Svendsen et al. 2002). Highest concentrations of suspended inorganic particulate matter were observed in the inner fjord of Kongsfjorden during spring in the surface waters under fast ice, reaching values of $20 \mathrm{~g} \mathrm{~m}^{-3}$. The highest values of organic particulate matter were also found in the spring surface waters of the inner fjord, with values reaching $26 \mathrm{~g} \mathrm{~m}^{-3}$. By late summer the total suspended solids were $1 \mathrm{~g} \mathrm{~m}^{-3}$, with a water column residence time of 20-23 days. By comparison, the residence time in ice-covered sea is 52-293 days (Cochran et al. 1995).

Generally, both fjords can be described as having glaciomarine depositional environments with sediment supply from the glaciers directly into the basins in both a proximal and distal setting. Icebergs can carry sediments into the fjord by ice rafting and entrain sediment during grounding and scouring (Dowdeswell \& Forsberg 1992). Highest sedimentation rates are found adjacent to the glaciers, with decreasing sediment input away from the glaciers. Localized resedimentation can occur in the deeper basins, where oversteepened slopes can lead to a failure and the deposition of glacigenic debris flows and turbidites (Howe, unpubl. data).

\section{Oceanography}

Oceanographically, the western Svalbard coast is influenced by two main currents, the West Spitsbergen Current (WSC) and Arctic Coastal Water. The upper $600 \mathrm{~m}$ of the WSC are dominated by warmer, more saline waters of Atlantic Water (AW). AW follows the continental slope, and produces the relatively ice-free conditions of western Svalbard (Vinje 2001). As a result of mixing with the Arctic Coastal Water, the Atlantic origin water entering Kongsfjorden differs from the AW flowing within the WSC and is thus termed Transformed Atlantic Water (TAW), which has lower salinity and temperatures values of $1{ }^{\circ} \mathrm{C}$ and 34.7 psu. TAW is principally confined to the intermediate waters whilst the deeper waters of the fjord basins contain colder waters, termed Local Water, with temperatures typically of $<1^{\circ} \mathrm{C}$. Local Water is the result of convection processes during autumn/winter cooling. Extremely cold water masses, with temperatures as low as $-1.4{ }^{\circ} \mathrm{C}$ and with relatively high salinities, are found filling the deepest basins. They result from winter cooling and sea ice formation (with associated brine rejection creating dense, very cold water). 


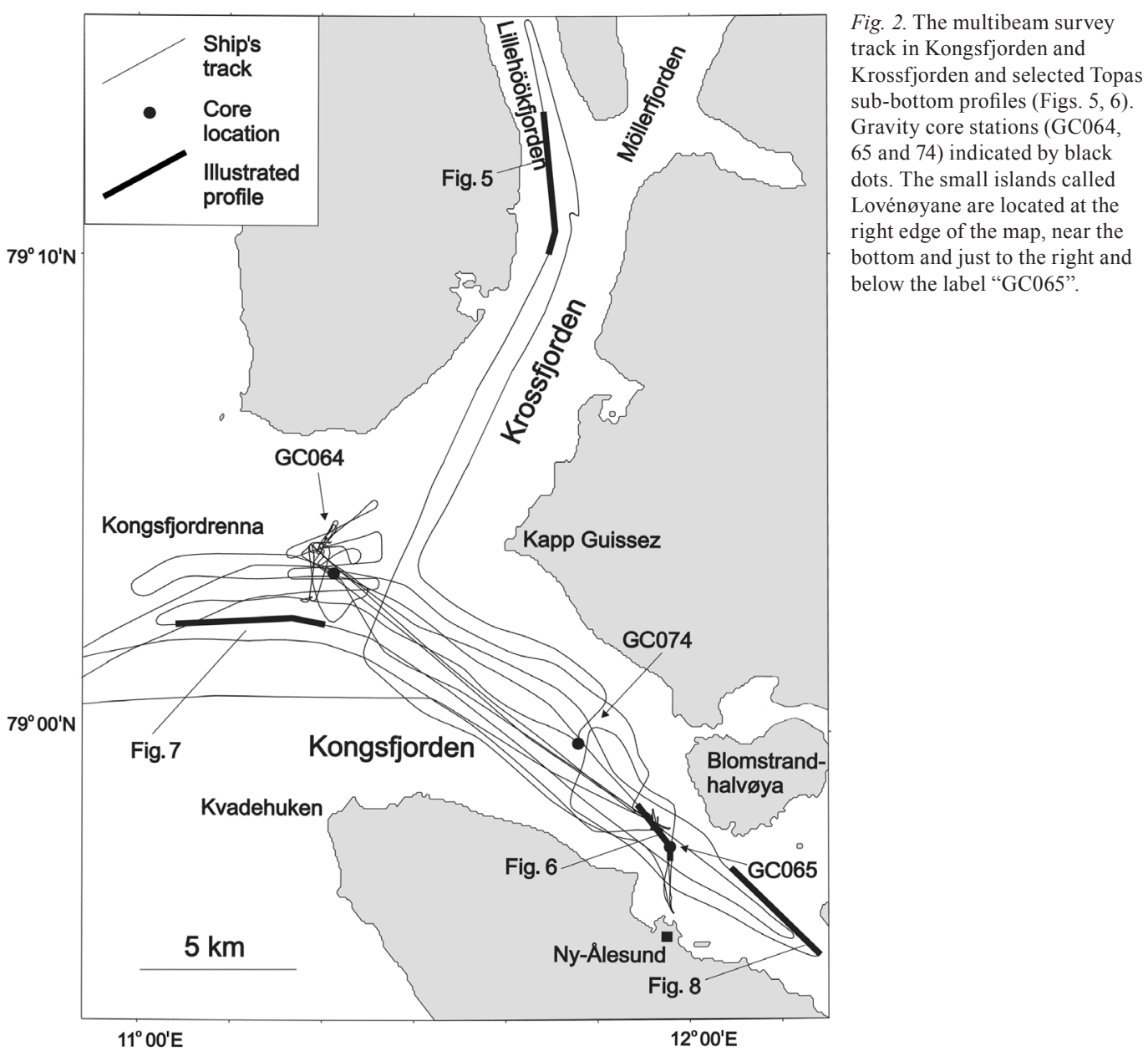

This water mass is termed Winter Cooled Water (Svendsen et al. 2002). Surface Water is characterized by decreased salinities of 28-30 psu and only occupies the upper few metres of the water column. Consequently, this water can undergo rapid solar heating and temperatures can reach $4^{\circ} \mathrm{C}$ in this brackish water layer.

Kongsfjorden and Krossfjorden can be considered a glacial fjord system (Svendsen et al. 2002). Kongsfjorden and Krossfjorden do not possess well-defined sills at their mouths. However, the glacial trough of Kongsfjordrenna contains water depths down to $350 \mathrm{~m}$, and shallows gradullly across the shelf. Processes operating in the fjords are dominated by seasonal variations, typically freshwater supply, water temperature changes, predominant wind-direction (upfjord in summer, down-fjord in winter) and sea ice formation/melt. An important process is rotational dynamics produced by the Coriolis Effect, which can aid water stratification and cause the inflow to generally hug the southern shore, with outflow following the northern shore. Freshwater is supplied by meltwater from the glaciers at the surface and at deeper levels by the calving and melting of icebergs. The freshwater influx is greater during the summer months and limited during the winter. The freezing and melting of fast ice in the inner fjords effectively removes freshwater to the surface layers and homogenizes the water stratification due to vertical convection initiated by salt rejection and freezing (Svendsen et al. 2002). A strong, well developed pycnocline causes flow in deep layers to be somewhat independent of surface (wind-driven) flow.

Multibeam bathymetry and depositional environments 


\section{Methods}

\section{Core sampling methods}

Core samples were obtained at all stations using the $6 \mathrm{~m}$ British Geological Survey gravity corer. The corer uses a $1000 \mathrm{~kg}$ weight and a $6 \mathrm{~m}$ long, $10 \mathrm{~cm}$ diameter steel barrel, within which is a polycarbonate liner. After the corer is run into the seabed at $40 \mathrm{~m} / \mathrm{min}$ and retrieved, the core is measured and sliced into 1-m sections. Following sectioning, the core was passed through a Bartington MS2 magnetic susceptibility loop onboard prior to splitting. Once split, the cores were logged and digitally photographed. Onshore laboratory work comprised bulk particle size analysis, using an LS230 Coulter Counter.

\section{Multibeam and Topas sub-bottom profiling survey methods}

Seabed mapping of Krossfjorden and Kongsfjorden (Fig. 2) was carried out using the hullmounted Simrad EM120 Multibeam bathymetry sonar system and the Topas sub-bottom profiling system on the RRS James Clark Ross. These two systems provide detailed data of the seabed morphology (EM120 Multibeam) and the sediment geometry and acoustic character (Topas) and were operated continuously throughout the cruise. Detailed surveys were made at each sampling station. The work within the fjords was conducted at a speed of 6 knots. Water column velocity profiles needed to correct the swath data were derived from ship-mounted Acoustic Doppler Current Profiler (ADCP) run in the survey area. Spurious depth values were edited from the bathymetry profiles using Simrad's Neptune software. The final data were contoured and displayed as shaded relief maps using the Generic Mapping Tool (Wessel \& Smith 1995). The coastline used to display the maps is from the $G E B C O$ digital atlas (IOC, IHO \& BODC 1997).

Topas uses a parametric acoustic source which produces a very narrow acoustic beam pattern. In the fjord area it was operated in "burst" mode set so that the transmitted pulse was equivalent to two periods of $2.8 \mathrm{kHz}$. The return signal was sampled at a frequency of $10 \mathrm{kHz}$ over a $400 \mathrm{msec}$ trace length. Subsequently, the recorded profiles were processed using filtering and time variant gain to enhance the sub-bottom reflectors.

Howe et al. 2003: Polar Research 22(2), 301-316

\section{Multibeam survey data}

\section{Seabed morphology}

The processed image of the multibeam bathymetry and interpretation are shown in Figs. 3 and 4. The seabed morphology is highly variable throughout Kongsfjorden, although generally Krossfjorden is somewhat flatter, containing less significant rough topography. Central and outer Kongsfjorden is dominated by outcrops of bedrock, presumably Devonian-age conglomerates and sandstones with a thin $(<10 \mathrm{~m})$ sediment cover. The bedrock mass extends over $30 \mathrm{~km}^{2}$, north into Krossfjorden, and displays an approximate NNW-SSE structural trend, enhanced by a relict sub-glacial, ice-scoured topography possibly produced during the last glaciation of the Pleistocene (Weichselian) and again during the last major readvance in the Holocene (Little Ice Age). The boundary between outer Kongsfjorden and the shelf glacial trough of Kongsfjordrenna is marked by the sill, rising from $350 \mathrm{~m}$ to $<50 \mathrm{~m}$ water depths and with a maximum width of approximately $2 \mathrm{~km}$. The sill is well developed in the north but flattens and becomes less well defined to the south in water depths of 250 to $300 \mathrm{~m}$. Kongsfjorden, with its rougher topography, contains two significant basins with flat, smooth seabed in water depths of over $350 \mathrm{~m}$. One in central Kongsfjorden, north of $\mathrm{Ny}-\AA$ Alesund, is fed by a channel from the inner fjord, trends north-west-south-east, has a width of $<50 \mathrm{~m}$ and is 5-10 $\mathrm{m}$ deeper than the surrounding seabed. The channel is interpreted to be a relict subglacial feature. The basin is surrounded by cliffs and steep slopes, with heights of between 100 and $150 \mathrm{~m}$. The deepest point $(-394 \mathrm{~m})$ in Kongsfjorden is found within a topographically confused basin $4.5 \mathrm{~km}$ north of Kvadehuken, surrounded by cliffs and smoothed bedrock highs. Significantly, central Kongsfjorden displays smoothed, teardrop-shaped lineations clearly visible south of Kapp Guissez and covering the bedrock highs in water depths $<200 \mathrm{~m}$. These features range in length from 1.5 to $2.5 \mathrm{~km}$, with widths of $<100 \mathrm{~m}$ and rising up to $10 \mathrm{~m}$ above the surrounding sea floor. The features have a high head and a long, smooth "tail" and are interpreted to be relict sub-glacial drumlins. The drumlins trend north-west-south-east on the north shore of central Kongsfjorden, changing counter-clockwise to trend south-west-north-east on the south shore of 


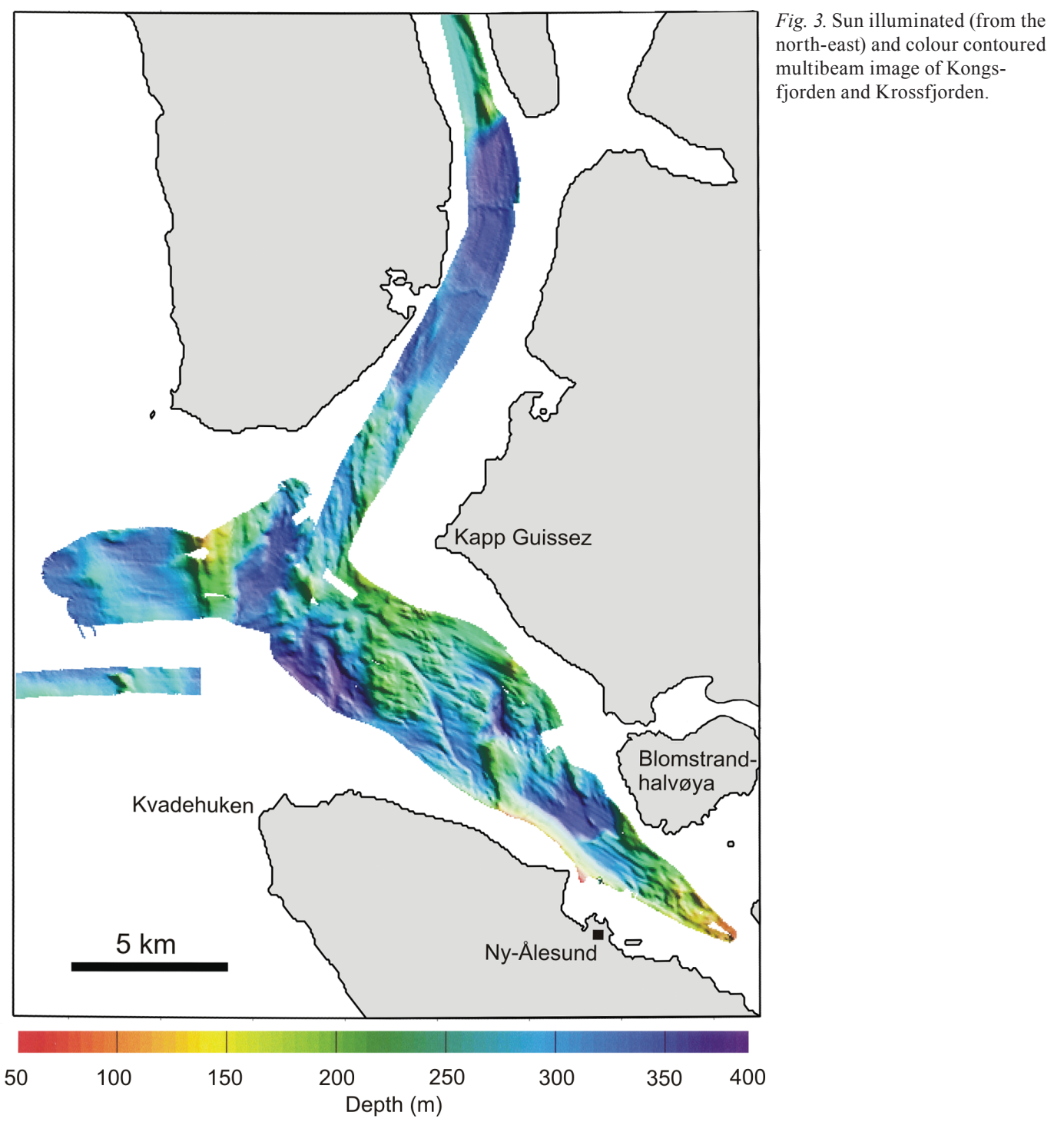

central Kongsfjorden.

Krossfjorden lacks any dramatic morphological features, although the outcrop of rough bedrock continues from Kongsfjorden into southern Krossfjorden before disappearing into the seabed. Krossfjorden is flatter, containing a smooth seabed interrupted by two small features, possibly channels fed by nearby rivers from the western shore, approximately 15 and $22 \mathrm{~km}$ from Lillehöökbreen glacier in the north. A steep, $100 \mathrm{~m}$ high slope is also present, marking the change from smooth, flat seabed in Krossfjorden to the more complex topography of Lillehöök- fjorden. On either side of the slope are the two ice-proximal and ice-distal basins illustrated in the sub-bottom profile of Fig. 5.

\section{Topas sub-bottom profiles}

The region can be divided into areas of dominant acoustic character based on the Topas sub-bottom profiles. Broadly, four main categories, found in both Kongsfjorden and Krossfjorden, can be recognized: (i) acoustically well-laminated with continuous parallel reflectors (Figs. 5, 6); (ii) paral-

Multibeam bathymetry and depositional environments 
Fig. 4. Seabed morphology interpreted from the multibeam bathymetry. Features highlighted include the currentmodified sub-glacial topography, including drumlin field. The currents are produced from the counter-clockwise circulation of wind-driven forcing of surface waters, leading to strong bottom boundary layer flow. The main channel supplying sediment to the main inner fjord basin off $\mathrm{Ny}$-Ålesund, is visible, interpreted as a relict sub-glacial feature. Also highlighted are the across-fjord channels in Krossfjorden, corresponding to the river mouths on the western shore, and the sediment-filled basins.

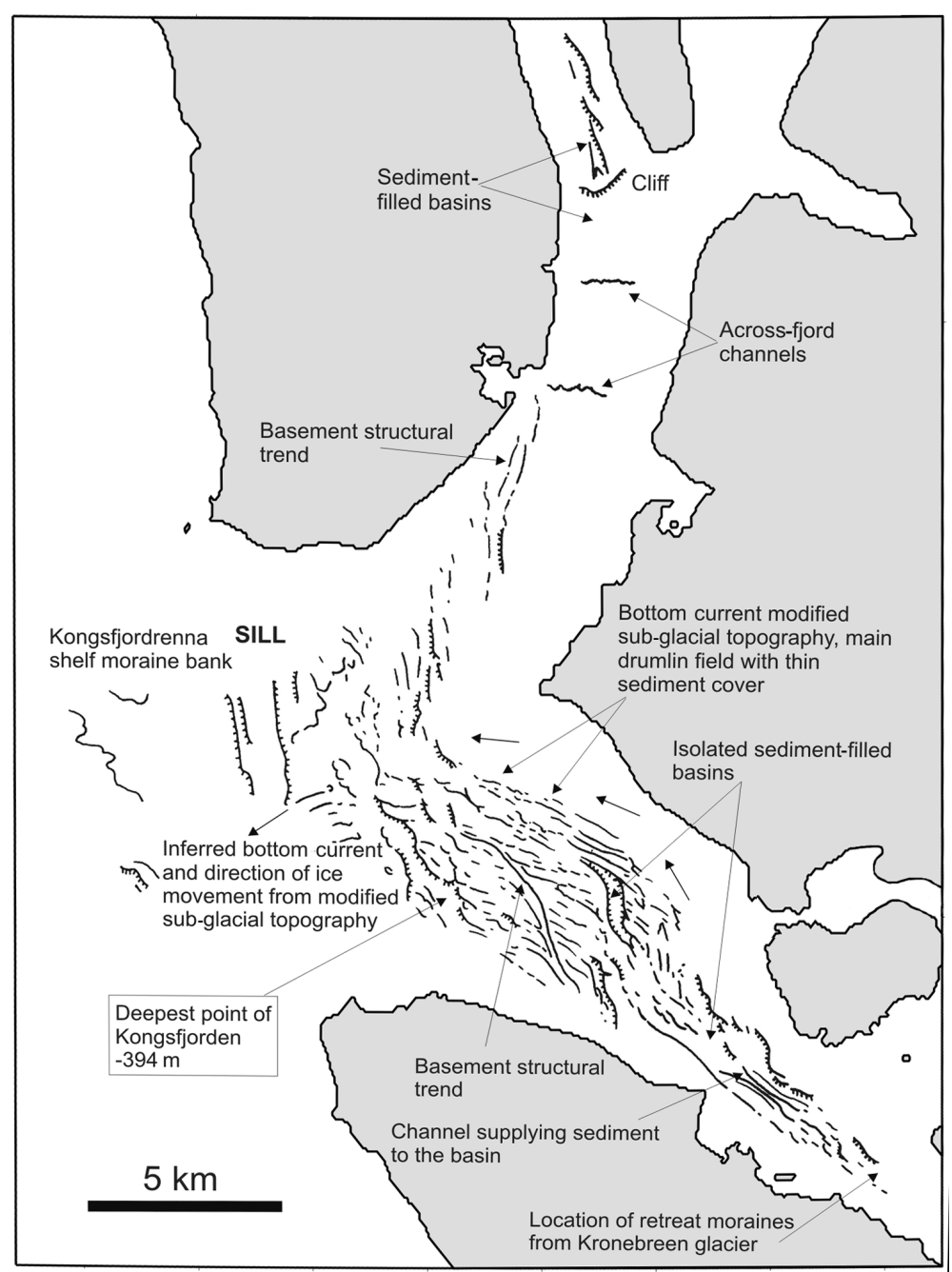

lel, irregular-transparent reflectors (Figs. 5, 6); (iii) transparent-chaotic reflectors (Fig. 6); and (iv) continuous, highly reflective (Figs. 7, 8). The detailed acoustic character and seismic stratigraphy of Krossfjorden and Kongsfjorden have been described previously by Elverhøi et al. (1983). Below we present an interpretation of the modern processes operating in the fjords based on the reflector characteristics illustrated in the sub-bottom profiles, followed by a summary of the stratigraphy of the depositional sequences that have resulted in the acoustic geometry displayed in the fjords, adapted from Elverhøi et al. (1983), Sexton et al. (1992) and Whittington et al. (1997).

Howe et al. 2003: Polar Research 22(2), 301-316

\section{Well-laminated, continuous parallel reflectors}

This acoustic character is dominant in the deepest basins of the two fjords, typically below water depths of $250 \mathrm{~m}$. The sediment package comprises up to $30 \mathrm{~m}$ of well-laminated continuous parallel reflectors that infill the seabed depressions (Figs. 5, 6). At the margins of most of the basins the reflectors display some onlapping. This is suggestive of deposition from settling from suspension. However, in some cases, notably the isolated basin north-west of $\mathrm{Ny}$-Ålesund in Kongsfjorden, the reflectors display a "ponded" character, indicative of turbiditic, downslope mass-movement. The well-laminated, continuous parallel sequence described here encompass- 


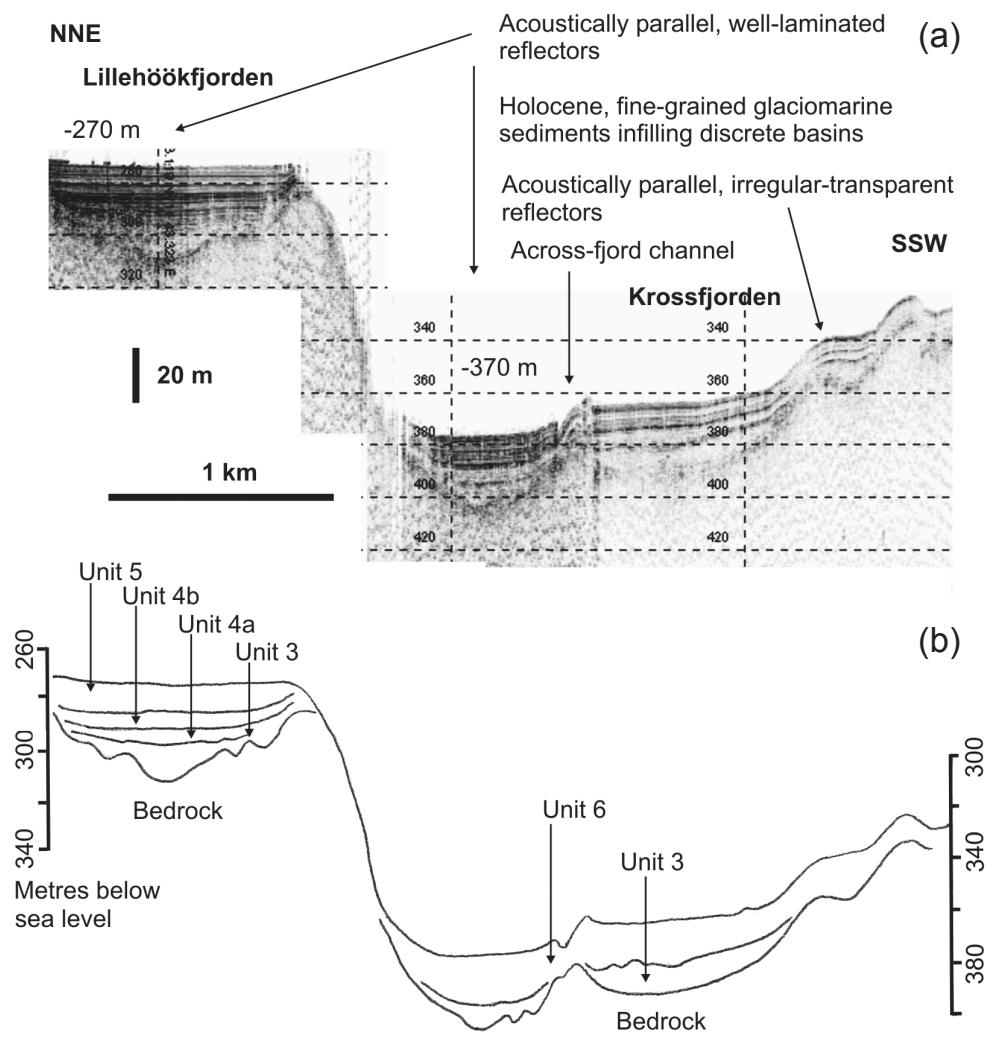

Fig. 5. (a) Topas sub-bottom profile of Lillehöökfjorden and Krossfjorden with the two main depositional basins of acoustically parallel, well-laminated reflectors interpreted as up to $30 \mathrm{~m}$ of Holocene (post-Little Ice Age) fine-grained glacigenic sediments separated by a 100 $\mathrm{m}$ high submarine cliff. The small channel is also visible, corresponding to change in acoustic character to parallel, irregular-transparent reflectors, down-fjord. (b) Interpretation of acoustic units based on Sexton et al. (Fig. 2 in 1992). Units 1 - 2 are not shown; they occur $5 \mathrm{~km}$ to the NNE and represent the Little Ice Age moraines. Units 3-6 (shown) are interpreted by Sexton et al. (1992) as a post-Little Ice Age fan complex of ice-proximal glaciomarine sediments.

es the Holocene Stratified Sequence as described by Whittington et al. (1997).

\section{Parallel, irregular-transparent reflectors}

The parallel, irregular-transparent reflections are common in both fjords, notably on the gentler slopes and in isolated lees of rougher topography. The sediment package is thin, suggesting a high acoustic impedance when compared to the welllaminated continuous parallel character of the basins. Typical sediment thickness is $10-15 \mathrm{~m}$ with drop-outs and transparent sections common (Fig. 6). This acoustic character is indicative of thin, more poorly-sorted sediments with possible significant gas content. This is also noted from the inner fjord in association with the moraines from Kongsbreen glacier. The parallel, irregulartransparent sequence described here also encompasses the Holocene Stratified Sequence as documented by Whittington et al. (1997).

\section{Transparent-chaotic reflectors}

A transparent or chaotic acoustic character is common on the flanks and at the base of steeper slopes in the fjords. The sediment package is up to $5 \mathrm{~m}$ thick and displays a wedge-shaped or lensoid geometry (Fig. 6). This character is interpreted to be minor downslope mass-wasting, possibly as small isolated debris flows on steep slopes, and as mixed, poorly sorted glaciomarine sediments.

\section{Continuous, highly reflective}

This is the most common acoustic character throughout both fjords. The continuous, highly reflective seabed is interpreted as possessing either a thin $(<2 \mathrm{~m})$ or non-existent sediment cover, or where coarse-grained or poorly sorted sediments provide a strong acoustic return. Typically occurring in the fjords' shallower regions $(<100 \mathrm{~m})$, this acoustic character is associated with the both the bedrock highs and morainal banks and moraines of Kongsfjorden (Figs. 7, 8).

Multibeam bathymetry and depositional environments 
Fig. 6. (a) Topas sub-bottom profile of the $355 \mathrm{~m}$ deep basin, north-west of Ny-Ålesund, Kongsfjorden, showing acoustically parallel, well-laminated reflectors infilling the basin interpreted as Holocene fine-grained glacigenic sediments. A minor debris flow is also visible in the north-west as a wedge-shaped lens of acoustically chaotictransparent reflectors. Gravity core GC065 was recovered from this station. (b) Interpretation of acoustic units based on Elverhøi et al. (Fig. 6 in 1983). The "distinct" and "semi-prolonged" bottom echoes, as described by Elverhøi et al. (1983), are here interpreted as the highly reflective and transparent-chaotic and parallel, well-laminated acoustic character. These are interpreted as Holocene (post-Little Ice Age) glaciomarine sediments.

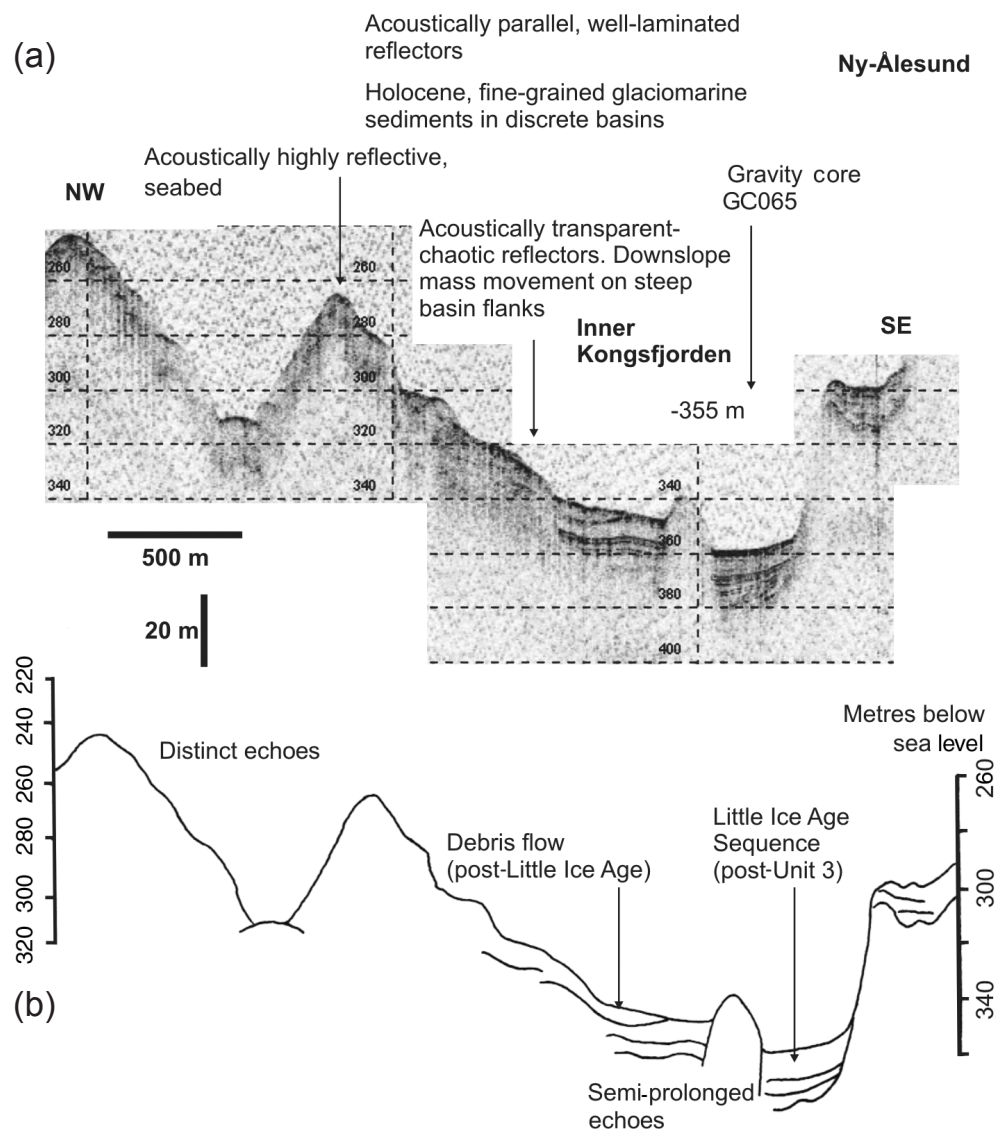

Krossfjorden and Lillehöökfjorden: acoustic character

Krossfjorden displays a simple acoustic character. The fjord is dominated by bedrock outcrops at its southerly reaches, adjacent to the merger with outer Kongsfjorden. Here Krossfjorden displays a highly reflective and chaotic-transparent character across the rough topography. This is interpreted as a thin cover of coarser glaciomarine sediments with some minor downslope movements. North, away from the influence of the icescoured topography of the drumlins and bedrock, the acoustic character changes, as does the morphology, with a smooth, flatter seabed and corresponding dominance of parallel, irregular-transparent acoustic character. Two discrete basins, containing a thicker sequence of well-laminated continuous parallel reflectors providing a sediment package up to $30 \mathrm{~m}$ thick (Fig. 5), are separated by a steep $100 \mathrm{~m}$ high slope. One basin lies at $270 \mathrm{~m}$ water depth in Lillehöökfjorden and one at $370 \mathrm{~m}$ water depth in Krossfjorden. These basins and their seismic stratigraphy have been described in detail by Sexton et al. (1992) and interpreted as a fan complex developed at the front of Little Ice Age moraines. The internal stratigraphy has been divided into units $1-6$, of which units 3-6 are illustrated here (see Fig. 5). An explanation of the seismic stratigraphy is provided below.

The small across-fjord channels visible on the multibeam image are also displayed as $<10 \mathrm{~m}$ deep asymmetrical channels cutting down into the well-laminated continuous parallel acoustic sequence. These channels may have originated from riverine bedload transport of sediments during seasonal melts providing dense, sedimentladen turbidites to the fjord floor. 


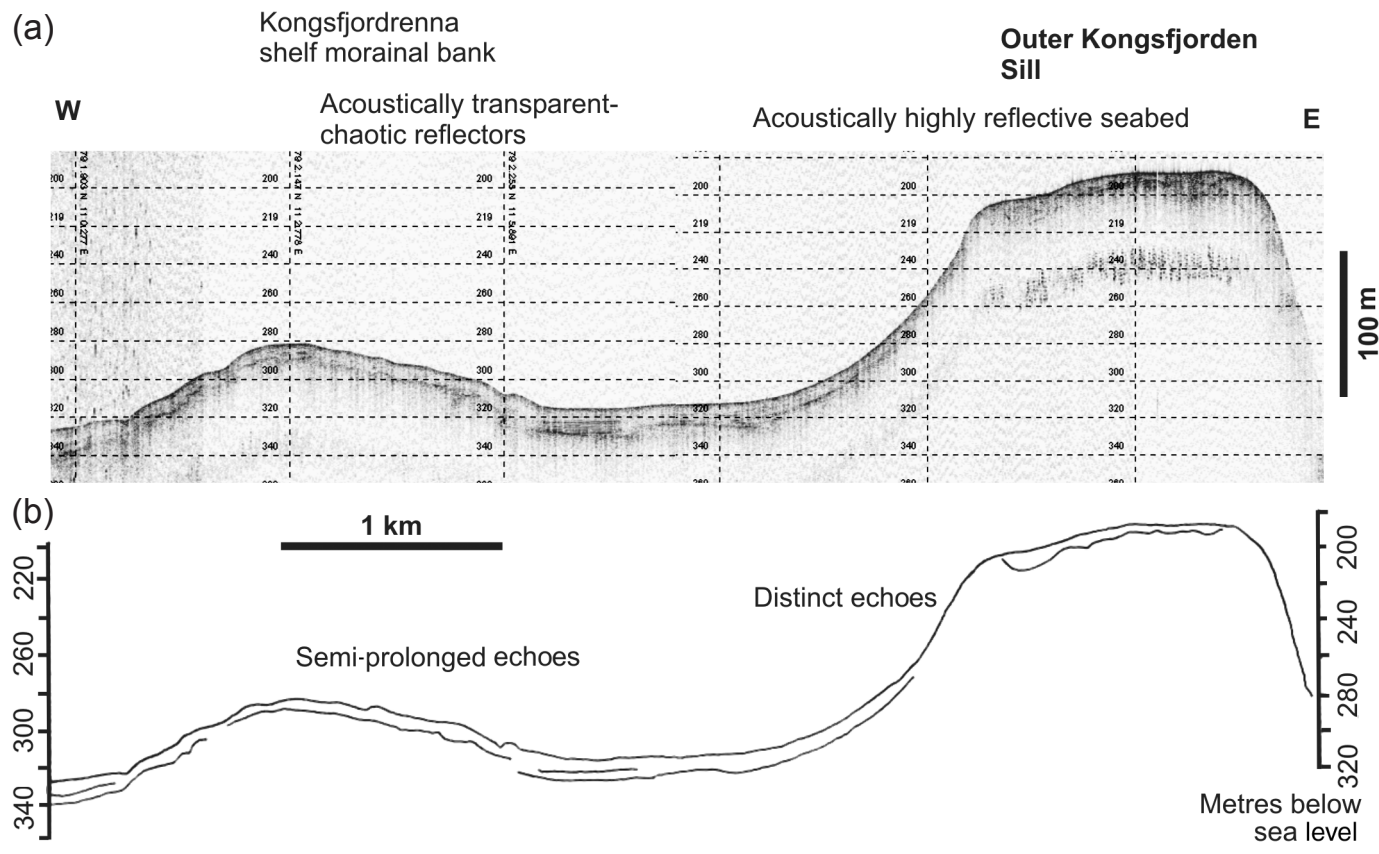

Fig. 7. (a) Topas sub-bottom profile of outer Kongsfjorden and Kongsfjordrenna showing the discontinuous sill with a highly reflective acoustic character. Two $\mathrm{km}$ west of the sill, a small bank of acoustically chaotic-transparent character is visible, interpreted as a moraine. (b) Interpretation of acoustic units based on Elverhøi et al. (Fig. 6 in 1983). The "distinct" and "semiprolonged" bottom echoes, as described by Elverhøi et al. (1983), are here interpreted as the highly reflective and transparentchaotic acoustic character.

\section{Outer Kongsfjorden: acoustic character}

Outer Kongsfjorden encompasses both Kongsfjordrenna (the glacial trough) and Kongsfjorden itself. Acoustically the area is dominated by a continuous, highly reflective character interpreted as being ice-scoured bedrock with thin sediment cover, and a coarser sediment dominated shelf in outer Kongsfjorden, including Kongsfjordrenna (Fig. 7). Within the glacial trough are isolated acoustically transparent packages of reflectors that pinch-out against isolated topographic highs interpreted as small, glacigenic mass-flows. In the outer fjord, a more significant, fine-grained sediment fill becomes more notable, with isolated sequences of well-laminated continuous parallel reflectors and acoustically chaotic-transparent packages. These are all indicative of fine-grained glaciomarine sedimentation, the chaotic and transparent units being interpreted as mass-flows and the well-laminated, continuous parallel, reflectors undisturbed recent sedimentation in the deeper $(>250 \mathrm{~m})$ basins.

\section{Central and inner Kongsfjorden: acoustic character}

Like outer Kongsfjorden, central and inner Kongsfjorden is characterized by an acoustically very varied character. The isolated basins are infilled with well-laminated continuous parallel reflectors and, irregular-transparent reflections indicating quiet, continuous, distal, fine-grained glaciomarine deposition (Fig. 6). A high organic content may have given rise to methane gas, producing gas-blanking of the profiles in places which is notable in the cores recovered. Minor mass-flows are also present against the flanks of topographic highs and are represented by acoustically chaotictransparent lensoid and wedge-shaped packages of reflectors. The topographic highs are sedimentfree, providing acoustically rough, highly reflective surfaces. Retreat moraines from Kongsbreen are also noted south-east of Blomstrandhalvøya, the profiles displaying a wave-like morphology and a highly reflective acoustic character (Fig. 8 ). These moraines correspond to the position of the maximum extent of the 1869 and 1948 surges

Multibeam bathymetry and depositional environments 

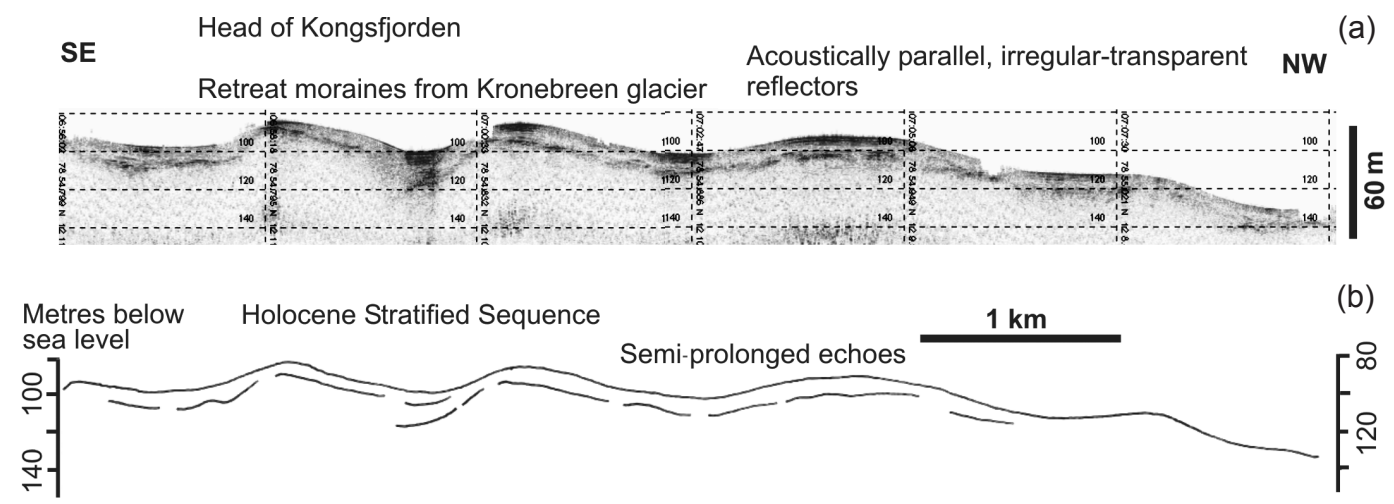

Fig. 8. (a) Inner Kongsfjorden, south-east of Blomstrandhalvøya, the profiles displaying a wave-like morphology and a highly reflective acoustic character interpreted as retreat moraines from the 1948 and 1869 surges of Kongsbreen glacier noted by Whittington et al. (1997). (b) Interpretation of acoustic units based on Elverhøi et al. (Fig. 6 in 1983) and Whittington et al. (Fig. 5 in 1997).

of Kronebreen glacier noted by Whittington et al. (1997).

\section{Seismic stratigraphy}

The new multibeam bathymetry and Topas subbottom profile data allow a comparison with earlier acoustic survey data across the fjords, notably the work of Elverhøi et al. (1983) on the echo character type mapping of Kongsfjorden, Sexton et al. (1992) on the basic seismic stratigraphy of Krossfjorden and Whittington et al. (1997) on the seismic signatures of ice-proximal sediments in inner Kongsfjorden. The profiles displayed here (Figs. 5-8) illustrate and extend the differing seismic stratigraphies adopted in these works. The lowest (oldest) seismic unit described (unit 3 of Sexton et al. 1992; and encompassing the "distinct" echo character of Elverhøi et al. 1983) is defined as being a blanket of possibly Late Weichselian-age glaciomarine sediments deposited from rapidly retreating ice. The intermediate stratigraphies (units 1 and 4 of Sexton et al. 1992 and including the "semi-prolonged", "transparent" and "semi-transparent" echo and transparency character of Elverhøi et al. 1983) are interpreted as post-Weichselian, pre-Little Ice Age sediments locally derived from tidewater glaciers within the fjords. The Little Ice Age stratigraphic units (unit 2 and including unit 5 of Sexton et al. 1992) are only displayed in Fig. 5 and are interpreted as Little Ice Age moraines and the upper part of the fan complex present in the iceproximal basin in Lillehöökfjorden. Post-Little
Ice Age deposition is represented by the uppermost seismic unit (unit 6 of Sexton et al. 1992 and including the Holocene Stratified Sequence of Whittington et al. 1997) and is interpreted as modern fine-grained sedimentation derived from particulate settling from the water column and distal glaciomarine sediments locally input via plumes from the glaciers.

\section{Sedimentology}

Three cores were recovered from Kongsfjorden only (see Fig. 2). Two from the central fjord basins, north of Ny-Ålesund, and one from the outer fjord, adjacent of the fjord mouth sill. Summary core information is provided in Table 1.

\section{Outer Kongsfjorden}

One core was retrieved from Outer Kongsfjorden, GC064 from the south-eastern flank of the fjord mouth sill in $307 \mathrm{~m}$ of water. The core is dominated by intensely bioturbated, gas-rich, dark greenish grey homogeneous muds containing many worm tubes of the Chaetopertid polychaete Spiochaetoperis typicus, as well as occasional lonestones and intact shelly material, notably bivalves and gastropods. Gas is a problem at this site and core disturbance cannot be discounted at this stage. The core is interpreted as distal organicrich glaciomarine muds, possibly as a result of settling from dilute fine-grained sediment and particulate suspensions. 


\section{Central Kongsfjorden}

Two cores were recovered from central Kongsfjorden: GC065 from $355 \mathrm{~m}$ from a small basin north of Ny-Ålesund and GC074 from $379 \mathrm{~m}$ from a similar small basin north-west of Ny-Ålesund. Both cores are dominated by dark greenish brown, intensely bioturbated muds with monosulphic knots, lonestones and S. typicus worm tubes common throughout. GC074 contained gradational sand layers at $2.70-2.90 \mathrm{~m}$ with a sharp, erosive lower contact and fining-upward trend. Both cores are interpreted as fine-grained glaciomarine muds resulting from settling from dilute fine-grained sediment and particulate suspension. The sandy layers in GC074 are interpreted as turbidites, indicating some slope instability within the fjord, possibly as a result of the high sediment supply producing oversteepened slopes in the basins, leading to subsequent failure.

\section{Modern sedimentary environments}

Kongsfjorden and Krossfjorden can be described as glaciomarine, ice-proximal sedimentary environments. Both have localized ice sources from the tidewater glaciers of Kongsbreen and Kronebreen in Kongsfjorden, and Lillehöökbreen into Lillehöökfjorden and thence into Krossfjorden (Whittington et al. 1997). The sedimentary environments of both fjords can be subdivided into basins (water depths $>250 \mathrm{~m}$ ), intermediate environments, including the central fjord bedrock banks (water depths between 250-100 m), and shallow water, including the fjord margins (water depths $<100 \mathrm{~m}$ ).

\section{Basinal environments}

The basins of the two fjords are all dominated by fine-grained, low energy deposition. Sedi- ment supply appears to be from three main processes: direct settling from the water column of clastic and particulate (both organic and inorganic) material; sediment redistribution from downslope movements; and alongslope transport of fine-grained material by geostrophic currents $\left(<10 \mathrm{~cm} / \mathrm{s}^{-1}\right.$; Svendsen et al. 2002). Of these processes the most important is direct settling from the water column. Both the sub-bottom profiles and the multibeam bathymetry provide evidence for the settling of sediments in the basins. The acoustic character of well-laminated, continuous parallel reflectors, with a draped geometry and the smooth, featureless morphology of the basin floors all indicate a low energy depositional environment. Occasional downslope mass-movements can occur, as noted from the turbidites in core GC074 and from the isolated transparent-chaotic lenses at the base of slopes interpreted as debris flows. These events may have resulted from oversteepening of the basin slopes from the high sediment supply or perhaps sediment distruption due to overturning icebergs or trawling activity.

\section{Intermediate environments}

Intermediate environments encompass the 250 $100 \mathrm{~m}$ zone and include the bedrock highs and slopes and the deeper fjord margins. Processes in this zone are dominated by a mixture of downslope and alongslope movements of sediment and the settling of material down through the water column. The multibeam image is testament to the ability of alongslope currents in intermediate and deep-water depths to entrain and transport finegrained sediments. The current has smoothed the morphology of the drumlins and other sub-glacial topography across the bedrock. The smooth $2 \mathrm{~km}$ "tail" behind a large obstacle, such as bedrock high or drumlin, is evidence of the persistent bottom boundary layer flow. The presence of

Table 1. Outer and central Kongsfjorden gravity core stations.

\begin{tabular}{|c|c|c|c|c|c|}
\hline Core number & Position & Water depth & Recovery & Description of area & General sediment type \\
\hline GC064 & $\begin{array}{l}79^{\circ} 03.03^{\prime} \mathrm{N} \\
11^{\circ} 21.54^{\prime} \mathrm{E}\end{array}$ & $307 \mathrm{~m}$ & $3.28 \mathrm{~m}$ & $\begin{array}{l}\text { Outer Kongsfjorden, on the south- } \\
\text { eastern flank of the sill, at fjord mouth }\end{array}$ & $\begin{array}{l}\text { Homogeneous greeny-grey } \\
\text { silt }\end{array}$ \\
\hline GC065 & $\begin{array}{l}78^{\circ} 57.46^{\prime} \mathrm{N} \\
11^{\circ} 54.49^{\prime} \mathrm{E}\end{array}$ & $355 \mathrm{~m}$ & $3.34 \mathrm{~m}$ & $\begin{array}{l}\text { Central Kongsfjorden main basin north } \\
\text { of Ny-Ålesund }\end{array}$ & $\begin{array}{l}\text { Homogeneous brown and } \\
\text { black silts }\end{array}$ \\
\hline GC074 & $\begin{array}{l}78^{\circ} 59.36^{\prime} \mathrm{N} \\
11^{\circ} 46.03^{\prime} \mathrm{E}\end{array}$ & $379 \mathrm{~m}$ & $3.48 \mathrm{~m}$ & $\begin{array}{l}\text { Central Kongsfjorden, small isolated } \\
\text { basin north-west of Ny-§̊lesund }\end{array}$ & Greeny-black muds and sands \\
\hline
\end{tabular}


an upstream obstacle (a bedrock high or large ice-rafted boulder) produces an accelerated flow leading to some seabed erosion or non-deposition. Down-current, the velocity of the flow decreases and the sediment is deposited. Current speeds in this zone have been measured by ADCP as $5-10 \mathrm{~cm} / \mathrm{s}^{-1}$ (Svendsen et al. 2002). These current velocities are well within the parameters for the transport and deposition of fine sand and siltsized sediments.

\section{Shallow environments}

The shallow water environments of the fjords show the influence of ice, both from the tidewater glaciers at the heads of the fjords and from seasonal sea ice formation and subsequent iceberg scouring leading to sediment disturbance in the shallower water. Dowdeswell \& Forsberg (1992) document iceberg scouring in Kongsfjorden down to $40 \mathrm{~m}$ only, the product of the larger, calved icebergs from the glaciers, rather than seasonal sea ice. The seasonal formation of ice has a number of notable influences on the shallow water areas surrounding the fjords. The contribution of meltwater containing ice-rafted sediments can supply high volumes of material into shallow water either directly in front of the calving glacier or during the spring thaw as direct rain-out from sea ice. Once the fjord becomes ice-free during late spring or early summer, the prevailing processes are wave and wind-driven, reworking the shoreface and redistributing sediments on steeper slopes.

\section{Discussion}

The multibeam image and sub-bottom profiles from Kongsfjorden and Krossfjorden display a number of features that indicate the modern sea floor processes operating in the fjord. Most significantly in terms of sediment redistribution is the influence of bottom currents. The seabed morphology visible on the multibeam image is interpreted as relict sub-glacial features, such as drumlins and glacial flutes subsequently modified by bottom current flow from the wind-driven forcing of surface waters, leading to a strong bottom boundary layer in the central and outer fjord. From the trend of the features, the inferred flow of bottom currents in central Kongsfjorden is counter-clockwise-matching the meas- ured flow of bottom boundary layer flow under the influence of Coriolis forcing (Svendsen et al. 2002). This trend is also a pre-existing imprint of the direction of the original ice movement, east to west down Kongsfjorden and north-east to south-west down Krossfjorden, all towards the open sea, during the last glaciation. This glacial morphology could not have been produced by modern iceberg activity as the $20 \mathrm{~m}$ high Kongsbreen and Kronebreen tidewater glaciers do not produced large enough bergs to scour the seabed. The drumlins and flutes are all in excess of $100 \mathrm{~m}$ of water. These sub-glacial features represent an old glacial readvance, possibly the Last Glacial Maximum (Weichselian), certainly older than the "neoglacial" Holocene advance (Little Ice Age) thought to be not older than 4.5 Ky (Svendsen et al. 2002). Sexton et al. (1992) describe Weichselian glacial limits within the Kongsfjorden region as being $15 \mathrm{~km}$ beyond present positions. This would encompass the relict sub-glacial features imaged on the multibeam and include the shelf morainal bank in Kongsfjordrenna. Other authors have extended this Weichselian ice limit to include the shelf edge (Landvik et al. 1998; Mangerud et al. 1998). The features represent a relict sub-glacial topography, most likely a drumlin field, which has become subsequently modified by persistent modern bottom current activity. Relict drumlins have been observed on other submerged shelves, notably on the Ross Sea continental shelf, Antarctica (Shipp \& Anderson 1997). The Ross Sea drumlins are very similar to the features observed in Kongsfjorden, both in their geometry and height, and in their relationship to the sub-surface geology being formed on crystalline basement rocks and sedimentary strata.

A notable feature of the multibeam image is the lack of trawl marks on the seabed. Given the amount of trawling that can occur during the summer months in Kongsfjorden, the lack of visible trawl marks on the Topas sub-bottom profiles or the multibeam bathymetry is puzzling. Presumably the trawl marks are too small to be detected or the influence of trawling on the seabed is less than is assumed. Any large trawl markslarge enough to be detected by the multibeam survey - may have become smeared by the active bottom currents in the basin. Shears et al. (1998) describe trawl marks from side-scan sonar near $\mathrm{Ny}$-Ålesund. The frequency is unknown, but the trawlers generally work from $150 \mathrm{~m}$ depth in the 
inner part of Kongsfjorden (east of Ny-Ålesund) and seaward along the axis of the fjord (H. Hop, pers. comm. 2003). In the outer and central fjord the trawling may take different paths. The southeast-north-west orientation south of Kapp Guissez may indicate trawling into Krossfjorden, although the scales are larger than expected for trawl marks. Seabed photographs from inner Kongsfjorden display prominent common trawl marks on the seabed. In water depths of $350 \mathrm{~m}$ these are notable as they have become smoothed by bottom currents and are therefore of undefined age (D. Hughes, pers. comm. 2003).

The use of the sub-bottom profiles has enabled the identification of numerous minor downslope deposits in the deeper basins of the fjords, notably Kongsfjorden. Thin, wedge- and lensoidshaped packages of acoustically transparent and chaotic reflectors are visible on the flanks of topographic highs, significantly with the steep slope. These discrete debris flows are the product of gravitationally-induced sediment failure on the margins of the basins. A high sediment supply from the glaciers would lead to localized failures due to oversteepening of the slopes. Ice rafting can also lead to small-scale failure with an overturning iceberg dumping a slurry of partiallymelted sediments directly onto the sea floor.

The presence of gas-rich sediments is notable throughout Kongsfjorden and Krossfjorden both in the common occurrence of the chaotictransparent acoustic character and in recovered sediment cores. Fader (1997) discusses the influence of gas-rich sediments on seismic reflection profiles, describing acoustic blanking as "incoherent reflections" and a "bright spot". Gas-rich sediments are extremely common in marine basins, notably estuaries and bays where there is a high organic input. In Kongsfjorden and Krossfjorden, the high organic input may be from the decay of the high organic particulate matter, possibly phytoplankton, produced in the summer. The organic matter decays within the sediment and produces methane. In continental shelf basins, gas-release features such as pockmarks (Kelley et al. 1994) might be observed. No surface expression of pockmarks or other gas-release structures have been observed from either the Topas sub-bottom profiles or the multibeam image in Kongsfjorden and Krossfjorden.

The age of the sediments in the fjords is fundamentally linked to the age of the last full glacial readvance. The last readvance that filled the fjords with ice would have the effect of removing the sediment fill and transporting this out onto the shelf. Glacial retreat would provide a large sediment supply from the retreating glacier to the basins. The acoustically well-laminated sediment fill of the ice-proximal basins in both Krossfjorden and Kongsfjorden must therefore be all postLittle Ice Age, therefore younger than 1450-1800 $\mathrm{AD}$ (550 to 200 years ago). If this is the case then the $30 \mathrm{~m}$ of sediment thickness observed from the sub-bottom profiles represent a gross sediment accumulation rate of over $15 \mathrm{~cm} \mathrm{a}^{-1}$ (not taking into account compaction). Elverhøi et al. (1980) estimated a sedimentation rate at the ice front of Kronebreen and Kongsvegen of $>10 \mathrm{~cm} \mathrm{a}^{-1}$. However, the sub-bottom profiles illustrate the differing ages of some of the sediments in the fjords. The acoustically highly reflective seabed has been shown to be significantly older than the sediments in the basins, having been overcompacted by grounded ice yet not completely eroded (Elverhøi et al. 1983). In this sense the relict sub-glacial features such as the drumlins and the channel all predate the recent fine-grained sediment fill of the basins and may date synchronously with (if proximal to the glaciers of Lillehöökbreen, Kronebreen and Kongsvegen) or pre-Little Ice Age. During the Last Glacial Maximum, the fjords were totally ice-filled, with grounded ice extending out across the western Svalbard shelf by 22.5 Kya (Svendsen et al. 1992; Andersen et al. 1996). Glacial retreat occurred between 12 and 15 Kya (Jones \& Keigwin 1988; Svendsen et al. 1992; Andersen et al. 1996) with the fjords becoming ice-free by approximately 9 Kya. It must be assumed, therefore, that the sub-glacial topography observed from the multibeam bathymetry in Kongsfjorden and Krossfjorden date to a time when grounded ice filled the fjords during the Weichselian, reaching its shelfward limit during the Last Glacial Maximum. Mangerud et al. (1998) describe the chronology of ice sheet movement across the Svalbard-Barents region, with evidence for three major glaciations during the Weichselian, each one extending across the shelf, including the Kongsfjorden-Krossfjorden area. Landvik et al. (1998) discuss the minimum extent of the Weichselian ice sheet around Kongsfjorden, describing the work of Lehman \& Forman (1992), who describe the morainal bank (visible on the multibeam image presented here) as the minimum extent of the glacier, with deglaciation, dated from marine foraminifera on 
the proximal side of the moraine, occurring at approximately $12.3 \mathrm{Kya}$. On the basis of this evidence, we calculate that the sub-glacial features imaged by the multibeam bathymetry must be older than the ice-free date of 9 Kya.

Acknowledgements.-The authors would like to thank the officers and crew of RRS James Clark Ross for an enjoyable and successful cruise during the 2002 Arctic season. John Derrick (British Geological Survey) is thanked for the smooth operation of the onboard coring operation. We benefited from discussions about the physical oceanography with Finlo Cottier (Scottish Association for Marine Science [SAMS] Dunstaffnage Marine Laboratory). Haakon Hop (Norwegian Polar Institute) and Dave Hughes (SAMS) are thanked for information on trawling activities in Kongsfjorden. John Shaw and an anonymous reviewer are thanked for their useful comments which greatly improved the manuscript.

\section{References}

Andersen, E. S., Dokken, T. M., Elverhøi, A., Solheim, A. \& Fossen, I. 1996: Late Quaternary sedimentation and glacial history of the western Svalbard continental margin. Mar. Geol. 133, 123-156.

Bartek, L. R., Anderson, J. L. R. \& Oneacre, T. A. 1997: Substrate control on distribution of subglacial and glaciomarine seismic facies based on stochastic models of glacial seismic facies deposition on the Ross Sea continental margin, Antarctica. Mar. Geol. 143, 223-263.

Bergh, S. G., Maher, H. D. \& Braathen, A. 2000: Tertiary divergent thrust directions from partitioned transpression, Brøggerhalvøya, Spitsbergen. Nor. Geol. Tidsskr. $80,63-82$.

Cochran, J. K., Barnes, C., Achma, D. \& Hirshberg, D. J. 1995: Thorium-234/Uranium-238 disequilibrium as an indicator of scavenging rates and particulate organic carbon fluxes in the northeast water polynya, Swerland. $J$. Geophys. Res. 100(C3), 4399-4410.

DaSilva, J. L., Anderson, J. B. \& Stravers, J. 1997: Seismic changes along a nearly continuous $24^{\circ}$ latitudinal transect: the fjords of Chile and the northern Antarctic Peninsula. Mar. Geol. 143, 103-125.

Dowdeswell J. A. \& Forsberg, C. F. 1992: The size and frequency of icebergs and bergy bits derived from tide-water glaciers in Kongsfjorden, northwest Spitsbergen. Polar Res. 11, 81-91.

Elverhøi, A., Dowdeswell, J. A., Funders, S., Mangerud, J. \& Stein, R. 1998: Glacial and oceanic history of the Polar North Atlantic margins: an overview. Quat. Sci. Rev. 17, $1-10$.

Elverhøi, A., Liestøl, O. \& Nagy, J. 1980: Glacial erosion, sedimentation and microfauna in the inner part of Kongsfjorden, Spitsbergen. Geological and geophysical research in Svalbard and on Jan Mayen, 1980. Nor. Polarinst. Skr. 172, 33-61.

Elverhøi, A., Lønne, Ø. \& Serland, R. 1983: Glaciomarine sedimentation in a modern fjord environment, Spitsbergen. Polar Res. 1, 127-149.

Fader, G. B. J. 1997: The effects of shallow gas on seismic reflection profiles. In T. A. Davies et al. (ed.): Acoustic images of glaciated continental margins. Pp. 29-31. London: Chapman and Hall.

IOC (Intergovernmental Oceanographic Commission), IHO (International Hydrographic Organisation) \& BODC (British Oceanographic Data Centre) 1997: GEBCO digital atlas. 1997 edition. Published on behalf of the Intergovernmental Oceanographic Commission and the International Hydrographic Organisation as part of the General Bathymetric Chart of the Oceans. Birkenhead: British Oceanographic Data Centre.

Ito, H. \& Kudoh, S. 1997: Characteristics of water in Kongsfjorden, Svalbard. Proc. NIPR Symp. Polar Meterol. Glaciol. 11, 211-232. Tokyo: National Institute of Polar Research.

Jones, G. A. \& Keigwin, L. D. 1988: Evidence from Fram Strait $\left(78^{\circ} \mathrm{N}\right)$ for early deglaciation. Nature $336,56-59$.

Kelley, J. T., Dickson, S. T., Belknap, D. F., Barnhardt, W. A. \& Henderson, M. 1994: Giant sea-bed pockmarks: evidence for gas escape from Belfast Bay. Mar. Geol. 22, 59-62.

Landvik, J. Y., Bondevik, S., Elverhøi, A., Fjeldskaar, W., Magerud, J., Salvigsen, O., Seigert, M. J., Svendsen, J.-I. \& Vorren, T. 1998: The Last Glacial Maximum of Svalbard and the Barents Sea area: ice sheet extent and configuration. Quat. Sci. Rev. 17, 43-75.

Lehman, S. J. \& Forman, S. L. 1992: Late Weichselian glacier retreat in Kongsfjorden, west Spitsbergen, Svalbard. Quat. Res. 37, 139-154.

Mangerud, J., Dokken, T., Hebbeln, D., Heggen, B., Ingolfsson, O., Landvik, J. Y., Mejdhal, V., Svendsen, J.-I. \& Vorren, T. O. 1998: Fluctuations of the Svalbard-Barents sea ice sheet during the last 150000 years. Quat. Sci. Rev. 17, 11-42.

Miller, G. H., Serjup, H.-P., Lehman, S. J. \& Forman, S. 1989: Late Quaternary glacial history and marine environmental change, western Spitsbergen, Svalbard Archipelago. Boreas 18, 273-296.

Powell, R. D. \& Molnia, B. F. 1989: Glacimarine sedimentary processes, facies and morphology of the southwestern Alaskan shelf and fjords. Mar. Geol. 85, 359-390.

Sexton, D. J., Dowdeswell, J. A., Solheim, A. \& Elverhøi, A. 1992: Seismic architecture and sedimentation in northwest Spitsbergen fjords. Mar. Geol. 103, 53-68.

Shaw, J. \& Courtney, R. C. 1997: Multibeam bathymetry of glaciated terrain off southwestern Newfoundland. Mar. Geol. 143, 125-137.

Shears, J., Theisen, F., Bjørdal, A. \& Norris, S. 1998: Environmental impact assessment. Ny-Alesund international scientific research and monitoring station, Svalbard. Nor. Polarinst. Medd. 157.

Shipp, S. \& Anderson, J. B. 1997: Drumlin field on the Ross Sea Continental Shelf, Antarctica. In T. A. Davies et al. (eds.): Acoustic images of glaciated continental margins. Pp. 52-54. London: Chapman and Hall.

Svendsen, H., Beszczynska-Møller, A., Hagen, J. O., Lefauconnier, B., Tverberg, V., Gerland, S., Ørbaek, J. B., Bischof, K., Papucci, C., Zajaczkowski, M., Azzolini, R., Bruland, O., Wiencke, C., Winther, J.-G. \& Dallmann, W. 2002: The physical environment of Kongsfjorden-Krossfjorden, an Arctic fjord system in Svalbard. Polar Res. 21, 133-166.

Svendsen, J.-I., Mangerud, J., Elverhøi, A., Solheim, A. \&

Howe et al. 2003: Polar Research 22(2), 301-316 
Schuttenhelm, R. T. E. 1992: The Late Weichselian glacial maximum on western Spitsbergen inferred from offshore sediment cores. Mar. Geol. 104, 1-17.

Syvitski, J. P. M \& Praeg, D. B. 1989: Quaternary sedimentation in the St Lawrence estuary and adjoining areas, eastern Canada: an overview based on high resolution seismostraigraphy. Geogr. Phys. Quat. 43, 291-310.

Vinje, T. 2001: Anomalies and trends of sea-ice extent and atmospheric circulation in the Nordic seas during the period 1864-1998. J. Climatol. 14, 255-267.

Wessel, P. \& Smith, W. H. F. 1995: New version of the Generic Mapping Tools released. EOS Trans. 76, 329.

Whittington, R. J., Forsberg, C. F. \& Dowdeswell, J. A. 1997: Seismic and side-scan investigations of recent sedimentation in an ice-proximal glacimarine setting, Kongsfjorden, north-west Spitsbergen. In T. A. Davies et al. (eds.): Acoustic images of glaciated continental margins. Pp. 175-178. London: Chapman and Hall. 